\title{
SISTEMATIK REVIEW: DAMPAK PERKULIAHAN DARING SAAT PANDEMI COVID-19 TERHADAP MAHASISWA INDONESIA
}

\section{A Systematic Review: The Impact of Online Lectures during the COVID-19 Pandemic Against Indonesian Students}

\author{
Niken Bayu Argaheni* \\ Prodi Kebidanan Program Sarjana Terapan, Sekolah Vokasi, Universitas Sebelas Maret, \\ Jl. Ir. Sutami 36 A, Kentingan Surakarta 57126 telp. (0271) 662622 \\ E-mail: kinantiniken@gmail.com
}

\begin{abstract}
ABSTRAK
Latar belakang: Pembelajaran secara daring dan bekerja dari rumah bagi para tenaga pendidik merupakan perubahan yang harus dilakukan oleh dosen untuk tetap mengajar mahasiswa. Pendidikan dengan jarak jauh memiliki tujuan agar mutu pendidikan meningkatkan dan relevansi pendidikan serta meningkatkan pemerataan akses dan perluasan pendidikan. Pendidikan jarak jauh yang diselenggarakan dengan penjaminan kualitas yang baik dan sesuai dengan kebutuhan pemangku kepentingan merupakan salah satu mekanisme perluasan akses pendidikan tinggi.

Subjek dan Metode: Sistematik review menggunakan database: Google Scholar. Hasil pencarian yang memenuhi kriteria kemudian dilakukan analisis artikel.

Hasil: Pembelajaran daring memiliki beberapa dampak terhadap mahasiswa yaitu (1) pembelajaran daring masih membingungkan mahasiswa (2) mahasiswa menjadi pasif, kurang kreatif dan produktif, (3) penumpukan informasi/ konsep pada mahasiswa kurang bermanfaat, (4) mahasiswa mengalami stress, (5) peningkatan kemampuan literasi bahasa mahasiswa.

Kesimpulan: Pembelajaran daring memiliki beberapa dampak terhadap mahasiswa. Hal tersebut diharapkan dapat menjadi evaluasi agar pembelajaran daring dapat diupayakan diterima dengan baik oleh mahasiswa tanpa mengurangi esensi pendidikan itu sendiri.
\end{abstract}

Kata kunci: Daring, Mahasiswa, COVID-19 


\begin{abstract}
Background: Online learning and working from home for educators are changes that must be made by lecturers to keep teaching students. Distance education has the aim of increasing the quality of education and the relevance of education and increasing equitable access and expansion of education. Distance education, which is organized with good quality assurance and in accordance with the needs of stakeholders, is one of the mechanisms for expanding access to higher education.

Subjects and Method: Systematic review using the database: Google Scholar. The search results that meet the criteria are then analyzed for articles.

Results: Online learning has several impacts on students, namely (1) online learning still confuses students (2) students become passive, less creative and productive, (3) accumulation of information / concepts on students is less useful, (4) students experience stress, (5) increasing students' language literacy skills.

Conclusion: Online learning has several impacts on students. This is expected to be an evaluation so that online learning can be strived for to be well received by students without reducing the essence of education itself.
\end{abstract}

Keywords: Online, Students, COVID-19

\section{PENDAHULUAN}

Pandemi COVID 19 di Indonesia mulai terjadi pada bulan Maret 2020, dimulai dengan adanya korban positif di kota Depok. Setelah itu peningkatan kasuspun terjadi di seluruh wilayah Jabodetabek sehingga menjadi kawasan zona merah. Badan Nasional Penanggulangan Bencana (BNPB) mengeluarkan surat keputusan nomor 13 A terkait penetapan masa darurat akibat virus corona. Berdasarkan penetapan tersebut, Kementerian Pendidikan dan Kebudayaan (Kemendikbud) mengeluarkan Surat Edaran dari Menteri Pendidikan dan Kebudayaan Nomor: 36962/MPK.A/HK/2020 tertanggal 17 Maret 2020 tentang Pembelajaran secara Daring dan Bekerja dari Rumah dalam rangka Pencegahan Penyebaran Corona Virus Disease (COVID-19) ${ }^{[1][2][3][4]}$.

Pembelajaran merupakan inti dari proses pendidikan. Kualitas pendidikan menggambarkan kualitas pembelajaran. Peningkatan kualitas pendidikan dapat dilakukan melalui peningkatan kualitas pembelajaran $^{[5]}$. Pembelajaran secara daring dan bekerja dari rumah bagi para tenaga pendidik merupakan perubahan yang harus dilakukan oleh dosen untuk tetap mengajar mahasiswa. Pendidikan dengan jarak jauh memiliki tujuan agar mutu pendidikan meningkatkan dan relevansi pendidikan serta meningkatkan pemerataan akses dan perluasan pendidikan. Pendidikan jarak jauh yang diselenggarakan dengan penjaminan kualitas yang baik dan sesuai dengan kebutuhan pemangku kepentingan merupakan salah satu mekanisme perluasan akses pendidikan tinggi (6). Program Belajar Jarak Jauh (PBJJ) merupakan alternatif yang digunakan saat ini oleh setiap universitas untuk melaksanakan proses belajar mengajar walaupun tidak dengan tatap muka. Perubahan proses belajar dari tatap muka menjadi PBJJ merupakan suatu keputusan yang harus dilakukan oleh univeritas agar tujuan pendidikan dapat dilaksanakan secara efektif dan efesien. Universitas merupakan sebuah organisasi modern yang harus beradaptasi dengan perubahan lingkungan. Universitas di tengah pandemi COVID-19 harus tetap menjalankan proses belajar mengajar. dengan mengubahnya menjadi PBJJ. PBJJ ini menjadi tantangan bagi setiap universitas untuk tetap mejalankan tujuan pendidikan $^{[1]}$. 
Pandemi COVID-19 menyebabkan sebuah Universitas melakukan budaya adaptif. Tiga dimensi dan indikatornya adalah yaitu penciptaan perubahan, fokus pada konsumen/ pelanggan, dan pembelajaran organisasi. Penciptaan perubahan akan dilihat dari (1) cara universitas melakukan segala sesuatu cara yang fleksibel dan mudah dalam menghadapi perubahan, dan (2) kemampuan universitas dalam memberikan tanggapan terhadap perubahan-perubahan lain dalam lingkungan. Fokus pada konsumen (mahasiswa) dilihat dari (1) komentarkomentar dan saran-saran Mahasiswa yang bisa menyebabkan perubahan, (2) semua anggota (universitas) memiliki pemahaman yang dalam terhadap keinginan dan kebutuhan mahasiswa. Pembelajaran organisasi dilihat dari: (1) Universitas melakukan inovasi dan mengambil risiko dan (2) Universitas terus belajar dalam memnyikapi perubahan yang terjadi di lingkungan eksternal.(1)

\section{SUBJEK DAN METODE Kriteria Inklusi dan Kriteria Eksklusi}

Kriteria inklusi artikel yang digunakan: 1) artikel yang memaparkan tentang pembelajaran daring pada mahasiswa; 2) artikel ditulis dalam bahasa indonesia; 3) artikel yang diterbitkan memiliki bagian yang lengkap; 4) diterbitkan saat tahun 2020.

Kriteria eksklusi artikel meliputi:

1) tidak menggunakan bahasa Indonesia.

2) susunan artikel tidak lengkap.

\section{Alur Pencarian}

Pencarian dilakukan dengan menggunakan database Google Scholar menggunakan kata kunci: "dampak COVID 19 pembelajaran daring mahasiswa". Artikel yang muncul kemudian dipilah sehingga tidak ditemukan artikel dengan judul yang sama. Selanjutnya artikel disortir berdasarkan kriteria inklusi dan eksklusi yang telah ditentukan. Artikel yang mencantumkan abstrak saja akan dieliminasi. Sehingga diperoleh artikel yang akan dianalisis.

\section{Ekstraksi artikel}

Artikel yang sudah didapat kemudian dilakukan ekstraksi. Ekstraksi artikel berdasarkan penulis artikel, tahun terbit artikel, jumlah sampel yang digunakan, alat ukur yang digunakan, hasil penelitian yang dilakukan, dan database artikel.

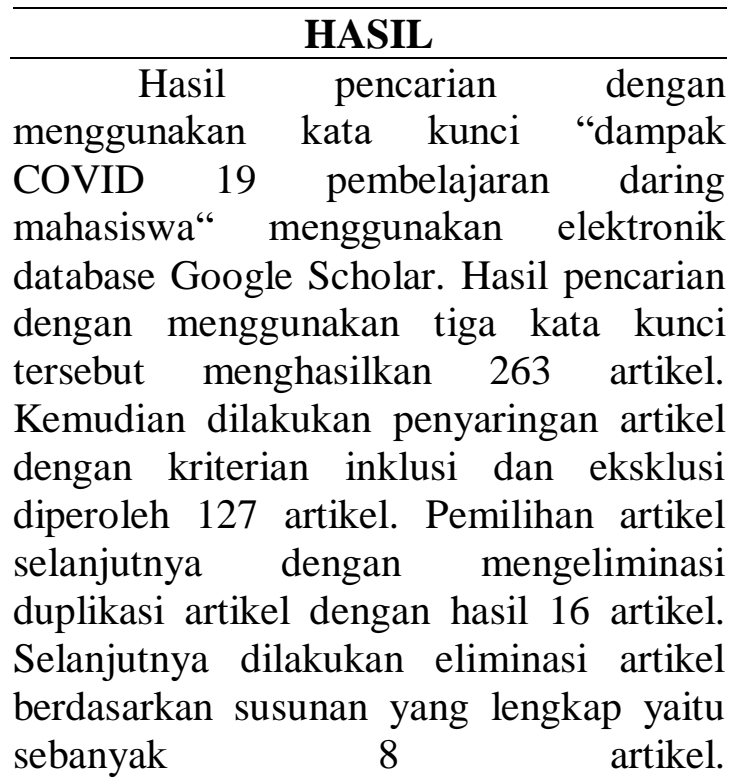

Tabel 1. Hasil Ekstraksi Artikel

\begin{tabular}{ccll}
\hline Penulis & Tahun & $\begin{array}{c}\text { Jumlah Subyek } \\
\text { Penelitian }\end{array}$ & \multicolumn{2}{c}{ Hasil } \\
\hline Dian Sari & 2020 & $\begin{array}{l}\text { 6 dosen dan 90 } \\
\text { mahasiswa }\end{array}$ & $\begin{array}{l}\text { Berdasarkan hasil penelitian, 3 universitas } \\
\text { sudah menjalankan peran adaptif sebagai }\end{array}$ \\
& & yang & universitas yang harus menyediakan PBJJ di \\
mengikuti & tengah pandemi ini. Namun, perbedaannya \\
& PBJJ dari tiga & terletak pada peran adaptif organisasi \\
& universitas & universitas. Peran adaptif universitas dilihat \\
& yang menjadi & dari penciptaan perubahan, fokus pada
\end{tabular}




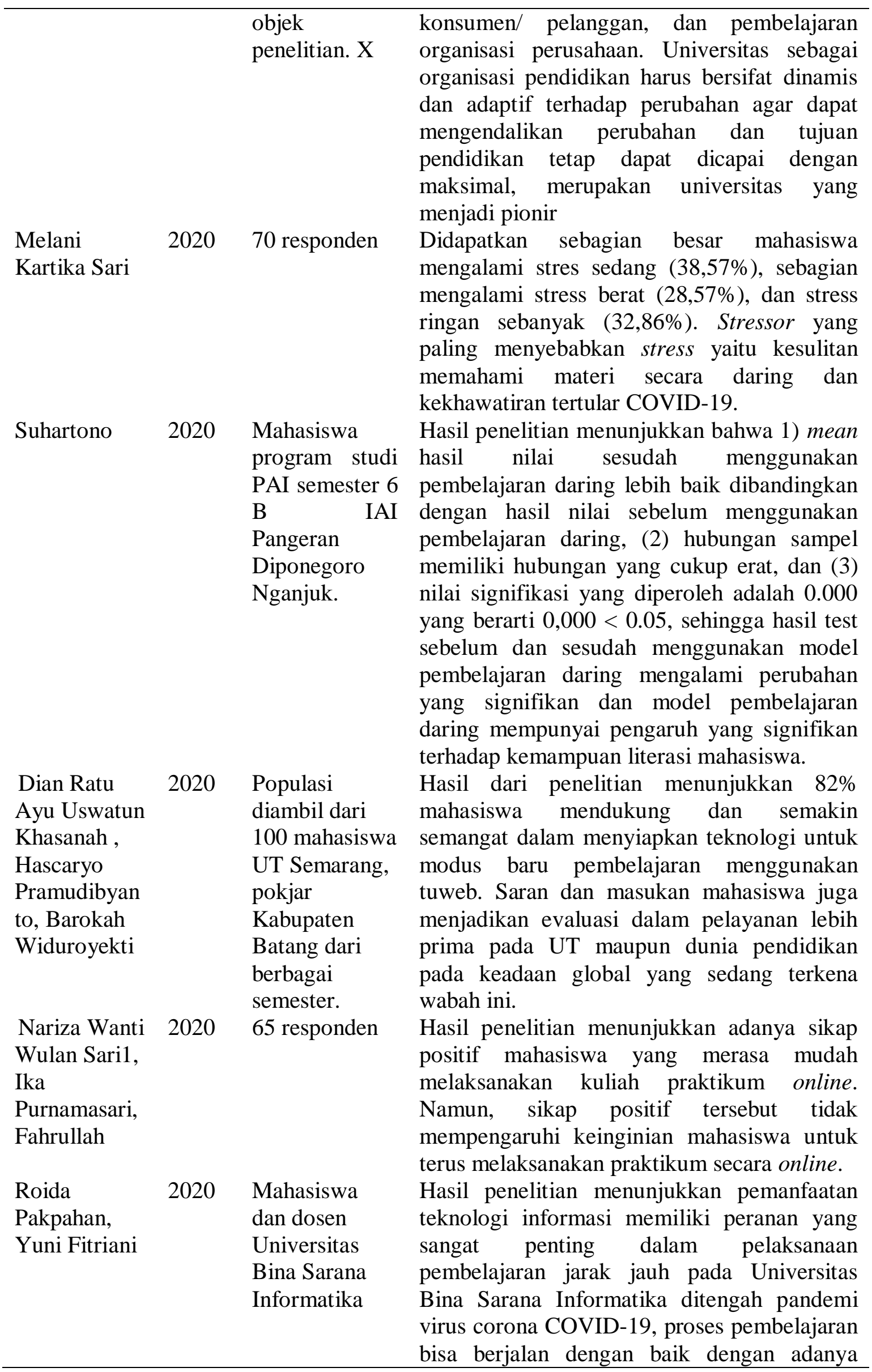




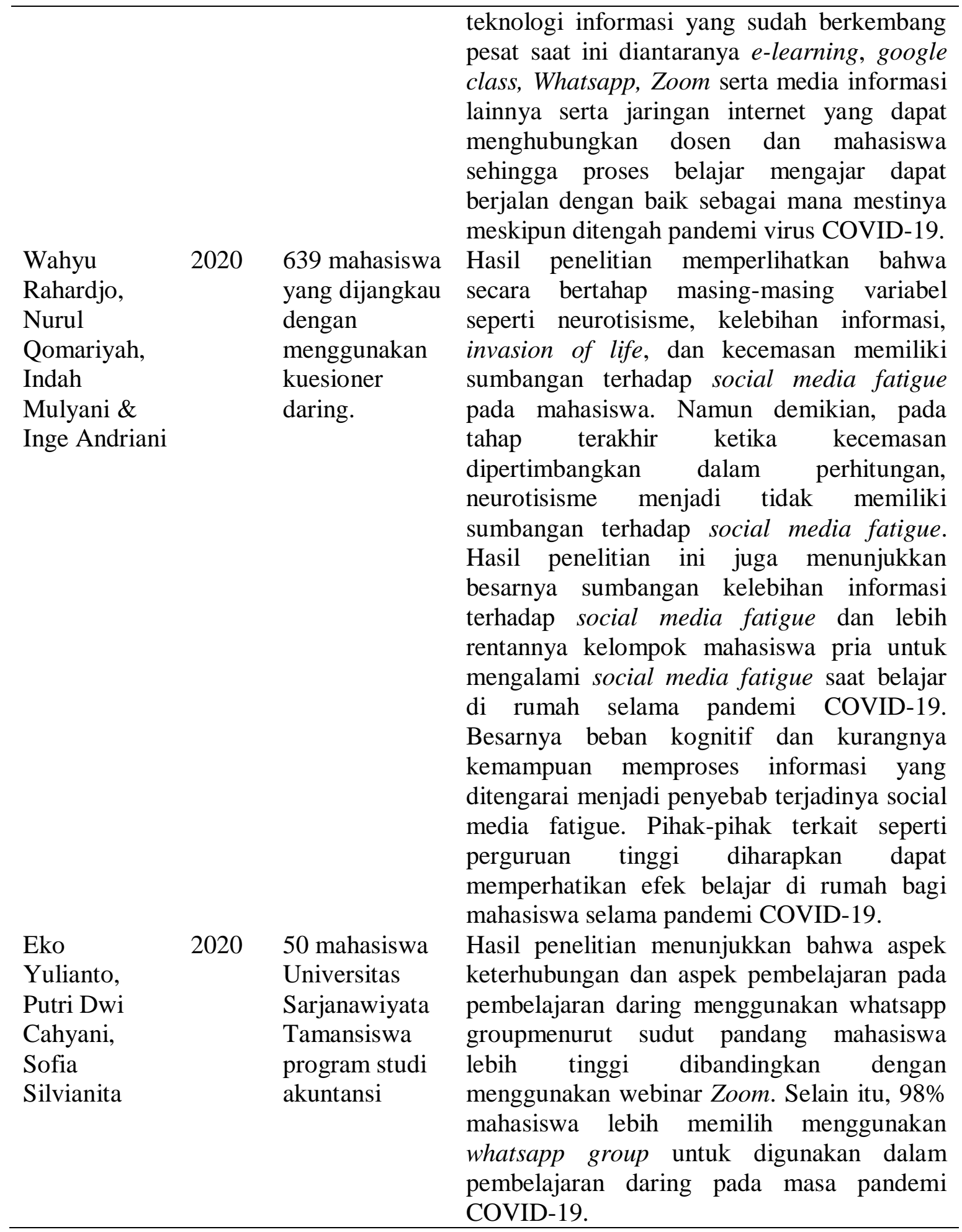

\begin{tabular}{l}
\hline \multicolumn{3}{c}{ PEMBAHASAN } \\
\hline Tranformasi pembelajaran dan sinergi \\
antar pendidikan tinggi diyakini dapat \\
menjadi salah satu kunci perguruan tinggi \\
untuk keluar dari krisis pandemi COVID- \\
19 yang berkepanjangan. Penggunaan \\
virtual learning dalam proses \\
pembelajaran jarak jauh diyakini
\end{tabular}

memberikan kemudahan belajar, menjadikan sarana untuk dapat berkomunikasi secara langsung via dunia maya, dan menghindari kontak fisik agar mencegah penularan COVID-19. Interaksi langsung memberikan sentuhan bermakna antara pendidik dan peserta didik, yang dapat merangsang pikiran, perasaan dan 
kemauan peserta didik. Melalui interaksi langsung, pendidik mampu mewujudkan suasana belajar dan proses belajar pembelajaran sesuai dengan karakter dan kebutuhan peserta didik serta pencapaian tujuan pendidikan. Lebih dalam lagi, interaksi secara langsung antara pendidik dan peserta didik mampu memunculkan perasaan saling membutuhkan, menghargai, kasih sayang, sampai perasaan rindu ketika peserta didik lulus dari mata kuliah yang diampu dosen tersebut $^{[7]}$.

Demi mengurangi persebaran virus COVID-19, pemerintah telah membuat kebijakan yakni physical distancing yang diantaranya berupa kebijakan khusus para peserta didik dimulai dari TK, SD, SMP, SMA sampai PT belajar dari rumah. Pendidik/guru, dosen, siswa, mahasiswa serta orang tua, berinteraksi melalui teknologi ${ }^{[8]}$. Kebijakan ini menjadi hal yang tentu membuat para pendidik untuk gencar melatih dan membiasakan diri terhadap perubahan yang akan terjadi. Cepatnya penyebaran virus ini dan korban positif yang semakin meningkat membuat Presiden Joko Widodo menetapkan wabah virus Corona COVID-19 ini sebagai bencana nasional. Beberapa aturan dan kebijakan terus dilakukan untuk menekan penyebaran dan memutus mata rantai virus ini. Salah satunya dengan pemberlakuan kebijakan social distancing atau jarak sosial agar masyarakat menjaga jarak fisik untuk melindungi diri dari penyebaran virus ${ }^{[9]}$.

Sejalan dengan hal tersebut bekerja dari rumah, belajar dari rumah, beribadah dari rumah dan menjaga jarak dan kesehatan diri diberlakukan. Sekolah dan universitas sebagai lembaga pendidikan formal tentu harus merespon dan mengambil sikap akan situasi ini dengan tepat. Aktivitas pembelajaran di sekolah dan universitas di seluruh Indonesia dihentikan, sebagaimana tertuang dalam Surat Edaran Mendikbud Nomor 4 Tahun 2020 tentang Pelaksanaan Kebijakan Pendidikan Dalam Masa Darurat
Penyebaran Corona Virus Desease (COVID-19). Kesehatan lahir dan batin mahasiswa, pendidik dan seluruh warga sekolah menjadi pertimbangan utama penghentian aktivitas pendidikan di sekolah dan univerisitas ${ }^{[9]}$.

Ketika kegiatan di sekolah "diliburkan", bukan berarti aktivitas belajar tidak dilakukan. Mendikbud dengan tegas menyatakan bahwa ruang aktivitas belajar dipindahkan dari sekolah ke rumah sehingga proses pembelajaran tetap berjalan seperti biasa. Salah satu cara dalam pembelajaran jarak jauh yang dilakukan adalah dengan menerapkan pembelajaran daring atau online. Pemanfaatan tekhnologi di era globalisasi dapat dimaksimalkan dalam situasi seperti ini $^{[9]}$. Sistem pembelajaran online berbasis proyek memberikan banyak peluang untuk mengakses bahan ajar oleh warga pembelajar. Banyak platform maupun media online yang bisa diakses melalui jaringan internet oleh pengajar maupun peserta didik. Beberapa hal yang menjadi kendala dalam penerapan pembelajaran online diantaranya kuota internet yang terbatas $^{[10]}$ dan masih belum familiarnya tenaga pendidik beserta peserta didik dalam mengaplikasikannya ${ }^{[11]}$.

Pembelajaran daring merupakan pembelajaran "dalam jaringan" sebagai terjemahan dari istilah online yang bermakna tersambung ke dalam jaringan komputer pembelajaran daring (online) sebagai strategi pembelajaran yang menyenangkan bagi pebelajar (mahasiswa) karena dapat menyimaknya dengan melalui smartphone, laptop, maupun komputer bukan hanya sekedar menyimak buku. Pembelajaran daring memiliki beberapa manfaat, di antaranya dapat (1) meningkatkan kadar interaksi pembelajaran antara mahasiswa dengan dosen, (2) memungkinkan terjadinya interaksi pembelajaran dimana dan kapan saja, (3) menjangkau mahasiswa dalam cakupan yang luas, dan (4) mempermudah penyempurnaan dan penyimpanan materi pembelajaran. Aktivitas belajar 
mahasiswa dengan pembelajaran daring (online) dapat membuat mahasiswa tidak merasa bosan, semakin tertarik, dan aktif dalam mengikuti pembelajaran ${ }^{[12]}$,

Kebermaknaan belajar, kemudahan mengakses, dan peningkatan hasil belajar. [13].

Secara berangsur-angsur, banyak organisasi mengadopsi online learning sebagai metode penyampaian utama untuk melatih para pegawai. Meskipun penggunaan sistem belajar online merupakan sesuatu yang mahal dari segi penggunaan paket data, namun dapat ditarik suatu manfaat yang sangat besar dari strategi tersebut baik bagi peserta didik maupun bagi pendidik. Mahalnya pembelajaran online juga masih bisa terjangkau menggantikan biaya transportasi ketika harus datang ke $\operatorname{kelas}^{[13]}$.

\section{Pembelajaran daring masih membingungkan mahasiswa}

Salah satu hal yang menjadi perhatian dalam pembelajaran daring ini adalah implementasi dari pembelajaran. Barubaru ini banyak mahasiswa yang mengeluhkan tugas yang banyak tanpa adanya materi yang cukup sehingga mereka agak kewalahan dalam mengikuti proses pembelajaran. Bahkan aplikasi Whatsapp, e-learning, dan juga Zoom masih membingungkan bagi mahasiswa ${ }^{[9]}$. Perkuliahan daring memang membutuhkan adaptasi dan usaha agar dapat berjalan lancar. Selain itu dibutuhkan usaha untuk memahami materi yang biasanya disampaikan secara lisan menjadi tulisan dan video atau live streaming ${ }^{[14]}$. Namun sejalan dengan itu adanya beberapa keluhan yang dirasakan oleh para siswa dan mahasiswa dimana mulai dirasakan rasa bosan akibat monotonnya metode pembelajaran ${ }^{[15]}$.

Meskipun pergeseran paradigma pendidikan abad 21 yaitu informasi, komputasi, otomasi, dan komunikasi yang merupakan empat komponen penting sebagaimana yang disampaikan oleh
Kementrian Pendidikan dan Kebudayaan sebagai ciri dari pendidikan abad 21, namun pilihan aplikasi dalam pembelajaran daring tetaplah dibutuhkan bahkan pendidik dapat menggunakan lebih dari satu aplikasi atau menggabungkan pemakaiannya sehingga memudahkan mahasiswa untuk mengikuti pembelajaran ${ }^{[9]}$.

\section{Mahasiswa menjadi pasif, kurang kreatif dan produktif}

Hal selanjutnya yang perlu diperhatikan dalam pembelajaran daring adalah model pembelajaran yang digunakan oleh pendidik. Meskipun pembelajaran daring menggunakan berbagai aplikasi dilaksanakan, namun guru dan dosen tetap harus memperhatikan bagaimana model pembelajaran dan skenario dari pembelajaran yang akan dilaksanakan karena pembelajaran tanpa rencana yang matang akan menyulitkan pendidik dan mahasiswa dalam mencapai tujuan pembelajaran. Pada realitasnya masih banyak pendidik yang memiliki pemahaman bahwa belajar merupakan transmisi pengetahuan kepada para mahasiswa. Hal ini menyebabkan mahasiswa menjadi pasif, kurang kreatif dan produktif dalam mengembangkan potensinya. Berdasarkan hal tersebut, diperlukan pemahaman baru bahwa belajar merupakan ruang untuk mengembangkan seluruh potensi para mahasiswa dan mereka diberi kebebasan untuk mengembangkannya sendiri ${ }^{[9]}$.

\section{Penumpukan informasi/ konsep pada mahasiswa kurang bermanfaat}

Tidak dapat disangkal, bahwa konsep merupakan suatu hal yang sangat penting, namun bukan terletak pada konsep itu sendiri, tetapi terletak pada bagaimana konsep itu dipahami oleh mahasiswa. Pentingnya pemahaman konsep dalam proses belajar-mengajar sangat mempengaruhi sikap, keputusan, dan caracara memecahkan masalah, untuk itu yang terpenting adalah proses terjadinya belajar 
yang bermakna dan proses berpikir bagi mahasiswa. Pada umumnya mereka yang mendapatkan pembelajaran disekolah seringkali sulit untuk menerapkan pengetahuan yang diperolehnya dengan permasalahan yang terjadi di dunia nyata, sehingga pengetahuan yang diperolehnya seakan akan tidak berguna dalam kehidupan sehari-hari. Ini adalah tantangan yang dihadapi oleh pendidik untuk meningkatkan kompetensinya terutama dalam pembelajaran daring atau online ini. Hal ini dikarenakan pembelajaran daring bukanlah sekedar memberikan tugas tetapi bagaimana pembelajaran tersebut dapat bermakna sehingga mampu mengantarkan para mahasiswa menjadi manusia yang handal dalam memecahkan masalah-masalah dalam kehidupan ${ }^{[9]}$.

Bersama informasi akademis yang kerap dibagikan lewat media sosial maka berita mengenai COVID-19 ikut lalu lalang secara masif dan tidak terkendali di berbagai media sosial dan berpotensi menimbulkan social media fatigue pada mahasiswa. Kelebihan informasi telah terbukti menyebabkan social media fatigue karena membebani kognisi individu. Social media fatigue adalah perasaan subjektif pengguna media sosial yang merasa lelah, jengkel, marah, kecewa, kehilangan minat, atau berkurang-nya motivasi berkaitan dengan interaksi di berbagai aspek penggunaan media sosial karena banyaknya konten yang ditemui dalam media social. Social media fatigue menyebabkan individu kehilangan konsentrasi dan fokus terhadap apa yang harus dikerjakan. Hal ini memicu konsekuensi negatif lainnya yaitu penurunan performa belajar. Artinya, mahasiswa yang belajar di rumah selama wabah COVID-19 diduga tidak mampu menampilkan kinerja yang maksimal dan mengalami penurunan prestasi ${ }^{[16]}$.

\section{Mahasiswa mengalami stres}

Stres yang dialami mahasiswa akibat wabah COVID-19 ini dipengaruhi oleh munculnya rasa takut akan tertular COVID-19, kekhawatiran saat pergi keluar rumah, kebosanan saat melakukan social distancing, dan kesulitan memahami materi saat perkuliahan daring. Keterbatasan untuk melakukan aktivitas di luar serta kecemasan tertular virus COVID-19 yang ditunjukkan memberikan gambaran bahwa wabah ini menimbulkan stress tersendiri bagi mahasiswa. Pelaksanaan physical distancing ini tentu membutuhkan adaptasi bagi berbagai pihak. Terutama bagi mahasiswa yang harus melakukan perkuliahan secara daring semenjak mewabahnya virus corona $^{[14]}$.

Kesulitan muncul bukan hanya perkara keterampilan penggunaan teknologi, tetapi juga terkait dengan beban kerja yang besar mengingat ada banyak mata kuliah yang harus dihadapi dalam masa pandemi COVID-19 ini. Hal ini terjadi karena mahasiswa terbiasa dengan pembelajaran tatap muka secara reguler, sedangkan pembelajaran jarak jauh sebelumnya hanya dilakukan secara insidental. Sehingga perubahan pola pembelajaran ini memberikan permasalahan tersendiri bagi mahasiswa. munculnya tekanan dan stres pada mahasiswa yang melakukan pembelajaran jarak jauh. Pada titik ini, tekanan tentu menjadi terasa lebih berat, sehingga mahasiswa melakukan banyak coping stress di mana salah satunya adalah terlibat dengan penggunaan media sosial. Jadi pada titik ini, seharusnya media sosial menjadi salah satu jalan keluar meretas rasa bosan ataupun stres karena belajar di rumah. Hanya saja, keadaan menjadi berbeda selama pandemi COVID-19. Kelebihan informasi telah terbukti menyebabkan social media fatigue karena membebani kognisi individu ${ }^{[16]}$.

\section{Peningkatan kemampuan literasi bahasa mahasiswa}

Pembelajaran daring memiliki pengaruh yang signifikan terhadap kemampuan literasi bahasa mahasiswa, 
dimana pembelajaran daring mempunyai banyak keuntungan bagi mahasiswa, di antaranya dapat menciptakan komunitas pembelajaran, efisiensi waktu dan biaya pembelajaran, dan bahan belajar dapat di akses kapan saja dengan kecanggihan teknologi Pembelajaran daring berhubungan erat dengan kemampuan literasi bahasa mahasiswa. Mahasiswa dapat dianggap memiliki literasi, apabila mahasiswa memiliki kemampuan dasar berbahasa, yaitu membaca dan menulis. Untuk sumber baca dan tulis di era sekarang tidak dapat dilepaskan dari jaringan internet melalui smartphone, laptop, komputer, dan sebagainya. Penggunaan daring dapat meningkatkan kemampuan membaca, menghasilkan persepsi yang positif membaca, mendorong diskusi kelas, dan mengembangkan keterampilan membaca dan berpikir kritis. Karena pengguna internet semakin banyak, maka mendorong orang untuk mengunggah hasil karyanya termasuk dalam bentuk karya tulis. Kegemaran orang mencari bacaan di internet dan mengunggah tulisan, secara otomatis literasi membaca dan menulis meningkat. Oleh karena itu, literasi sangat perlu dipupuk agar generasi gemar membaca dan menulis. Apalagi pada era digital ini, segala sesuatu membutuhkan kemampuan literasi termasuk literasi bahasa ${ }^{[12]}$.

Fenomena COVID-19 memberikan tantangan tersendiri untuk dunia pendidikan, yang menuntut harus siap mengajar dan belajar secara online/ daring hingga menjadikan perkuliahan sarat dengan kompetensi, tepat, cermat dan cepat. Disisi lain kompetensi, system, dan teknis belum mendukung sepenunya untuk itu. Dikarenakan selama ini pembelajaran dilaksanakan oleh guru dan dosen terbiasa dengan pola lama dengan teacher centered, pembelajaran daring baru sampai pada wacana sebagai perangkat teknis, belum mengarah pada media pengubah cara berfikir dan bertindak, sebagai paradingma pembelajaran berbasis student center, untuk menjadikan siswa kreatif, inovatif yang menghasilkan karya, wawasan pembentukan siswa menjadi pembelajar sepanjang hayat ${ }^{[17]}$.

\section{KESIMPULAN}

Pembelajaran daring memiliki beberapa dampak terhadap mahasiswa yaitu pembelajaran daring masih membingungkan mahasiswa; mahasiswa menjadi pasif, kurang kreatif dan produktif,; penumpukan informasi/ konsep pada mahasiswa kurang bermanfaat; mahasiswa mengalami stress; serta peningkatan kemampuan literasi bahasa mahasiswa. Hal ini dapat menjadi evaluasi agar pembelajaran daring dapat diupayakan diterima dengan baik oleh mahasiswa tanpa mengurangi esensi pendidikan itu sendiri.

\section{SARAN}

Saat ini, penyebaran COVID-19 masih menunjukkan tren kenaikan sehingga praktisi pendidikan dan stakeholder perlu berinovasi dalam melaksanakan pembelajaran agar dapat terus bertahan.

\section{DAFTAR PUSTAKA \\ 1. Sari D. Peran Adaptif Tiga Universitas di Jabodetabek dalam Menghadapi Sistem Belajar Online Selama Pandemi COVID 19. 2020;25-32.}

2. Hikmah N, Amelia CR, Ariani D. Pengaruh Pemberian Masase Effleurage Menggunakan Minyak Aromaterapi Mawar terhadap Penurunan Intensitas Nyeri Dismenore pada Remaja Putri di SMK Negeri 2 Malang Jurusan Keperawatan. J Issues Midwifery. 2018;2(2):34-45.

3. Wanti N, Sari W, Purnamasari I. Kombinasi Metode Partial Least Square ( PLS ) dan Technology Acceptance Model ( TAM ): Evaluasi Pembelajaran ( Praktikum Online ). 
4. Pakpahan R, Fitriani Y. JISAMAR (Journal of Information System, Applied, Management, Accounting and Researh). 2020;4(2):30-6.

5. Diana Novita ARH. Plus Minus Penggunaan Aplikasi-Aplikasi Pembelajaran Daring Selama Pandemi COVID-19. Unimed Medan. 2020;(June):1-11.

6. Wahyudin D, Karim A, Saepurrohman A. Pengelolaan Pembelajaran Jarak Jauh: Kajian Dasar Hukum dan Respon Mahasiswa. Digit Libr UIN Sunan Gunung Jati [Internet]. 2020;1-11. Available from: http://digilib.uinsgd.ac.id/30652/

7. Mashuri H. PEMBELAJARAN DI MASA COVID-19 WORK FROM HOME. Dwiyogo WD, editor. Malang: Wineka Media Anggota; 2020. 66 p.

8. Saleh M. Merdeka Belajar di Tengah Pandemi COVID-19. :51-6.

9. Kosassy SO. Model Pembelajaran Kobeko Berbasis Web Blog (Balada Pendidikan Tinggi di Tengah Kepungan Wabah COVID-19). JVEIT. 2020;1(1):36-41.

10. Yulianto E, Cahyani PD, Silvianita S. Perbandingan Kehadiran Sosial dalam Pembelajaran Daring Menggunakan Whatsapp group dan Webinar Zoom Berdasarkan Sudut Pandang Pembelajar Pada Masa Pandemic COVID-19. 2020;3(2):331-41.

11. Arizona K, Abidin Z, Rumansyah R. Pembelajaran Online Berbasis Proyek Salah Satu Solusi Kegiatan Belajar Mengajar Di Tengah Pandemi COVID-19. J Ilm Profesi Pendidik. 2020;5(1):64-70.
12. Suhartono. ANALISIS PENGARUH PEMBELAJARAN DARING TERHADAP KEMAMPUAN LITERASI BAHASA MAHASISWA. Innovative. 2020;08(1):137-44.

13. Khasanah DRAU, Pramudibyanto H, Widuroyekti B. Pendidikan Dalam Masa Pandemi COVID-19. J Sinestesia [Internet]. 2020;10(1):418. Available from: https://sinestesia.pustaka.my.id/journ al/article/view/44

14. Sari MK. TINGKAT STRES MAHASISWA S1 KEPERAWATAN TINGKAT 19 AND ONLINE LECTURER AT KARYA HUSADA HEALTH INSTITUTE. 2020;31-5.

15. Amany D, Desire A. Pembelajaran Interaktif berbasis Gamifikasi guna Mendukung Program WFH pada saat Pandemic COVID-19. ADI Bisnis Digit Interdisiplin $\mathbf{J}$ [Internet]. 2020;48-55. Available from: https://adi-

journal.org/index.php/abdi/article/vie w/116

16. Rahardjo W, Qomariyah N, Mulyani I, Andriani I. Social media fatigue pada mahasiswa di masa pandemi COVID-19: Peranneurotisisme, kelebihan informasi, invasion of life , kecemasan, dan jenis kelamin. Psikol Sos. 2020;18(59).

17. Rusdiana A, Sulhan M, Arifin IZ, Kamludin UA. Penerapan Model POE2WE Berbasis Blended Learning Google Classroom Pada Pembelajaran Masa WFH Pandemic COVID-19. Karya Tulis Ilm UIN Bandung 2020. 2020;1-10. 